\title{
YIELD STRESS MODIFICATION IN THE STRIP YIELD MODEL
}

\begin{abstract}
SUMMARY
From among of the deterministic models for fatigue crack growth predictions suitable for metallic materials a Strip Yield (SY) model can be considered the most general and powerful crack growth prediction tool owing to its applicability to arbitrary variable amplitude load histories. The SY model based on the conception of plasticity at the crack tip according to Dugdale, modified to accounting for the crack closure phenomena. The original Dugdale model is only valid for plane stress state conditions at the crack tip. Accounting for the triaxial stress conditions at the crack tip requires the yield stress modification, what is usually realized by using the suitable constraint factors. In the paper several concepts of the yield stress modification in the SY model have been described and notified. As it has been concluded the another important role of the constraint factors, in addition to accommodating in the SY model the triaxial stress state, is covering indirectly various processes which do affect crack growth, but cannot be treated in a rigorous way.
\end{abstract}

Keywords: fatigue crack growth prediction, Strip Yield model, constraint factors

\section{MODYFIKACJA GRANIC PLASTYCZNOŚCI W MODELU PASMOWEGO PEYNIĘCIA}

Spośród deterministycznych modeli do prognozowanie rozwoju pęknięć zmęczeniowych za koncepcję najbardziej ogólna uważany jest model pasmowego płynięcia (model SY), który może być zastosowany w przypadku dowolnych zmiennoamplitudowej historii obciażenia. Opiera się on na modelu plastyczności w wierzchotku pęknięcia wg Dugdale'a zmodyfikowanym w celu uwzględnienia zjawiska zamykania się pęknięcia spowodowanego uplastycznieniem materiału. Oryginalny model Dugdale'a odnosi się jedynie do płaskiego stanu naprężenia. Uwzględnienie trójosiowego charakteru stanu naprężenia wymaga w zwiazku z tym odpowiedniej modyfikacji granic plastyczności, co dokonywane jest na ogót przy użyciu odpowiednich wspótczynników skrępowania. W artykule omówiono i poddano ocenie istniejace koncepcje modyfikacji granic plastyczności w modelu pasmowego plynięcia. Wykazano, że poza uwzględnieniem trójosiowego charakteru stanu naprężenia dodatkowa istotna rola wspótczynników skrępowania w modelu pasmowego ptynięcia jest odzwierciedlenie w sposób pośredni szeregu zjawisk wpływających na proces zmęczeniowego rozwoju pęknięcia, których nie można uwzględnić w sposób ścisty.

Słowa kluczowe: przewidywanie rozwoju pęknięć zmęczeniowych, model pasmowego płynięcia, wspótczynniki skrępowania

\section{INTRODUCTION}

According to the damage tolerance philosophy, currently adopted by many industrial branches, various types of flaws are unavoidable in a structure. From this reason determination of the service life of a component subject to fatigue loading requires crack growth predictions. Depending on whether the crack increment in a given load cycle is uniquely determined from the input data or it is deemed a random variable, probabilistic and deterministic prediction models can be differentiated. The probabilistic approaches, which otherwise start from deterministic models, are amply considered elsewhere (e.g. Sobczyk and Spencer 1992, Danielecki 1997). A number of deterministic crack growth prediction models based on the plasticity induced crack closure phenomena discovered by Elber (1971), because an opinion prevails that fatigue crack growth behaviour of metals is to a large extent controlled by this mechanism. Especially the influence of the stress ratio, stress level and thickness as well as load interaction phenomena occurring under VA loading are attributed to crack closure. According to crack closure concept the fatigue crack growth rate $(\mathrm{d} a / \mathrm{d} N)$ in a given load cycle is controlled by the effective stress intensity factor $\Delta K_{\text {eff }}=K_{\max }-K_{o p}$, where $K_{\max }$ and $K_{o p}$ are the maximum stress intensity factor level and a level at which the crack fully opens on loading respectively. A common feature of fatigue crack growth prediction models based on crack closure effect is identifying the material's memory of a previous load history with the distribution of residual plastic stretches in the crack wake.

Depending on the way the crack opening level is determined, currently available crack closure models for fatigue crack growth prediction can be grouped in 3 categories, namely the semi-empirical concepts, the finite element codes and the strip yield (SY) model. With the semi-empirical models, relationships and rules to calculate the $K_{o p}$ are derived from observations on the crack growth behaviour in fatigue tests under various types of loading. The finite elements analyses are not suitable to predict crack growth under realistic, service-simulating load histories, primarily because the computation time and expense involved are incomparable with other prediction approaches. Regarding above the SY model is considered the most general and powerful crack growth prediction tool owing to its applicability to arbitrary variable amplitude load histories (Skorupa 1996, 1998). 


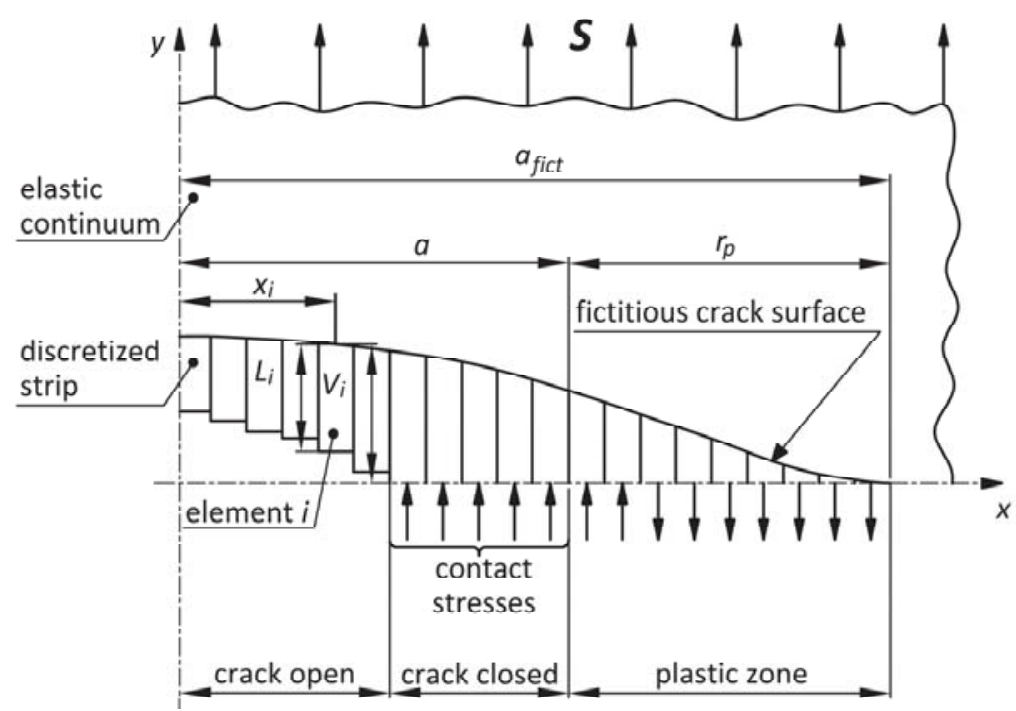

Fig. 1. Schematic of discretized plastic strip in the Strip Yield model

As it is well known, the SY model is based on the Dugdale conception of crack tip plasticity modified to allow forming a wedge of plastically deformed material on the surfaces of an advancing crack. As it has been shown on Figure 1 all plastic deformation is confined within an infinitely thin strip located along the crack line and embedded in perfectly elastic material. The strip stresses and deformations are solved using numerical methods by considering compatibility conditions along the fictitious crack surface. To this end, the plastic strip is divided into a number of bar elements. The elements in the plastic zone can carry both tensile and compressive stresses, whilst the broken elements in the crack wake can only undergo compressive stresses referred to as the contact stresses. The applied crack opening stress $\left(S_{\mathrm{op}}\right)$ for a given load cycle is determined from the contact stress distribution. The original Dugdale model is only valid for plane stress state conditions at the crack tip. However, depending on the stress level, thickness, crack length, the distance to the free boundary and the material stress-strain constitutive response actual stress conditions at the crack tip typically oscillate between the plane stress and plane strain state. Consequently, ahead of the crack tip stresses in the direction normal to the crack plane can exceed the material yield stress. In order to accommodate in the SY model a more general case of triaxial stress state, constraints on yielding the strip elements are imposed. Thus

$$
\sigma_{t}=\alpha_{t} \cdot \sigma_{0}, \quad \sigma_{c}=-\alpha_{c} \cdot \sigma_{0} \quad \text { and } \quad \sigma_{w}=-\alpha_{w} \cdot \sigma_{0}
$$

where $\sigma_{0}$ is the material flow stress, whilst $\alpha_{t}, \alpha_{c}$ and $\alpha_{w}$ are the constraint factors in the crack tip tensile plastic zone, compressive plastic zone and crack wake respectively, which define the local flow stresses $\sigma_{t}, \sigma_{c}$ and $\sigma_{w}$ in these regions.

According to the von Mises plasticity theory, the constraint factor, defined as maximum principal stress to the yield stress ratio $\left(\alpha=\sigma_{1} / \sigma_{y}\right)$, adopts for metallic materials
(Poisson's ratio of 0.3) values between the limiting levels of 1 and 3 corresponding to the plane stress and plane strain state respectively. The present paper is focused on the various constraint factors conceptions which can be incorporated into SY models. The description of the existing proposals of constraint factors variations and connected with them consequences for the prediction results are addressed in the paper.

\section{TENSILE YIELD STRESS MODIFICATION}

Newman (1981) was the first to account for 3D stress conditions at the crack tip in his SY model implementation named FASTRAN by introducing a constraint factor $\left(\alpha_{t}\right)$ on yielding in the crack tip plastic zone at the maximum applied cyclic stress $\left(S_{\max }\right)$. In the SY model, an ideally plastic material stress-strain response is assumed. To address the strain hardening effect Newman (1981) and others (e.g. Wang and Blom 1991) adopted $\sigma_{0}=\left(\sigma_{y}+\sigma_{u}\right) / 2$, where $\sigma_{u}$ is the material ultimate strength. In these earlier SY model implementations, the 3-D constraint under compressive yielding conditions was ignored, which implied constraint factors of unity in the compressive zone ahead of the crack tip and in the crack wake.

As illustrated in Figure 2, the $\alpha_{t}$-value significantly affects the crack opening level predicted by the SY model, especially at relatively low applied stresses (low $S_{\max } / \sigma_{0}$ ) and low stress ratios $(R)$. However, it turned out that with a constant, solely material and thickness dependent, $\alpha_{t}$ it was not possible to obtain a correlation between predictions and test results for a variety of stress amplitudes (Newman 1981). Such results suggested that the $\alpha_{t}$-value should vary with stress conditions at the crack tip during crack growth (Newman 1982, Wang i Blom 1991), which gave rise to developing new concepts of the constraint factors. 


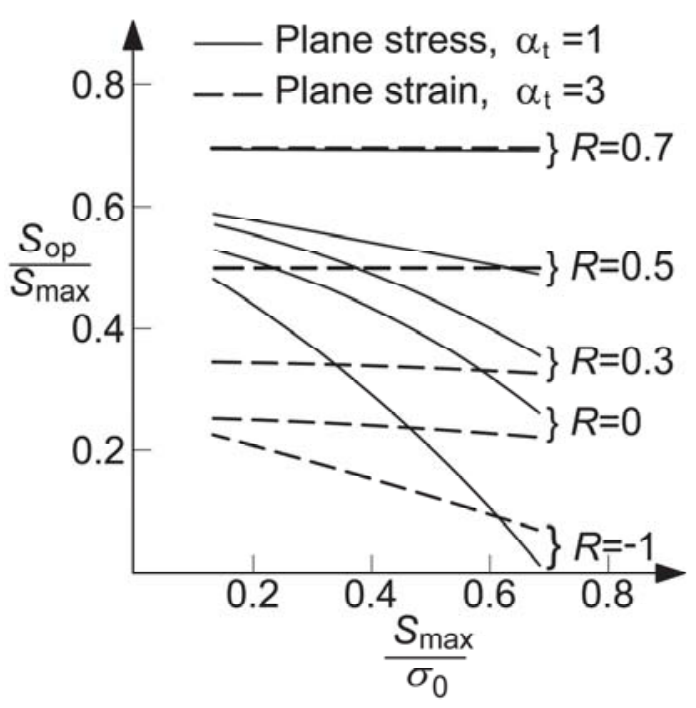

Fig. 2. The influence of $\alpha_{t}$ constraint factor on crack closure level calculated with FASTRAN model (Newman 1981)

For example, in a SY model by Wang i Blom (1991) named CLOTEST, $\alpha_{t}$ was related to the tensile plastic zone size at the crack tip $\left(r_{p}\right)$ for the current load cycle and the specimen thickness $(t)$ according to

$$
\alpha_{t}=\left\{\begin{array}{cll}
1 & \text { for } & r_{p} \geq t / 2 \\
\sqrt{t / 2 r_{p}} & \text { for } & t / 18<r_{p}<t / 2 \\
3(\text { or } 1.75) & \text { for } & r_{p} \leq t / 18
\end{array}\right.
$$

With Eq. 2, $\alpha_{t}$ is scaled between a value of unity, associated with the plane stress condition that occurs when $r_{\mathrm{p}} \geq t / 2$, and a value of 3 (von Mises theory), or alternatively 1.75 (Irwin model), when plane strain conditions, corresponding to $r_{p} \leq t / 18$, prevail. Because the $r_{p}$ and $\alpha_{t}$ parameters are interrelated, an iterative procedure is needed to determine the constraint factors.
The constraint factor remaining invariable during crack growth has also been abandoned in posterior works by Newman. For example, Newman et al. (1993) postulated that the constraint factor in the tensile plastic should be equal to the so called global constraint factor $\alpha_{G}$. The latter was determined from three-dimensional elastic-plastic FE analyses as a constraint factor averaged over the crack tip plastic zone according to the following equation:

$$
\alpha_{G}=\frac{1}{A_{T}} \sum_{m=1}^{M}\left(\frac{\sigma_{y y}}{\sigma_{y}}\right)_{m} A_{m}
$$

where $\left(\sigma_{y y} / \sigma_{y}\right)_{m}$ is the normalized stress normal to the crack line in element $m$ of the plastic zone, $A_{m}$ is the area of element $m$ and $A_{T}$ is the total area of all $M$ elements in the plastic zone. Variations of $\alpha_{G}$ with crack growth are illustrated in Figure 3 for several values of the crack length normalized by the specimen width $(a / W)$ and for several specimen thicknesses $(t)$.

Guo et al. (1999) related the above mentioned numerical solution for $\alpha_{G}$ by Newman et al. to the plane stress plastic zone size normalized by the specimen thickness $\left(r_{p} / t\right)$. The resulting mathematical relationship reads:

$$
\alpha_{G}=\frac{1+a\left(\sqrt{r_{p} / t}+2\left(r_{p} / t\right)^{2}\right)}{1-2 v+b\left(\sqrt{r_{p} / t}+2\left(r_{p} / t\right)^{2}\right)}
$$

where $v$ denotes Poisson's ratio, while $a$ and $b$ are constants ( $a=0.6378, b=0.5402)$.

Another concept of modifying the local tensile yield stress in the SY model was contributed by McMaster and Smith (2001). By matching the SY model predictions to fatigue crack growth observed under constant amplitude (CA) loading and after a single tensile overload (OL) on middle

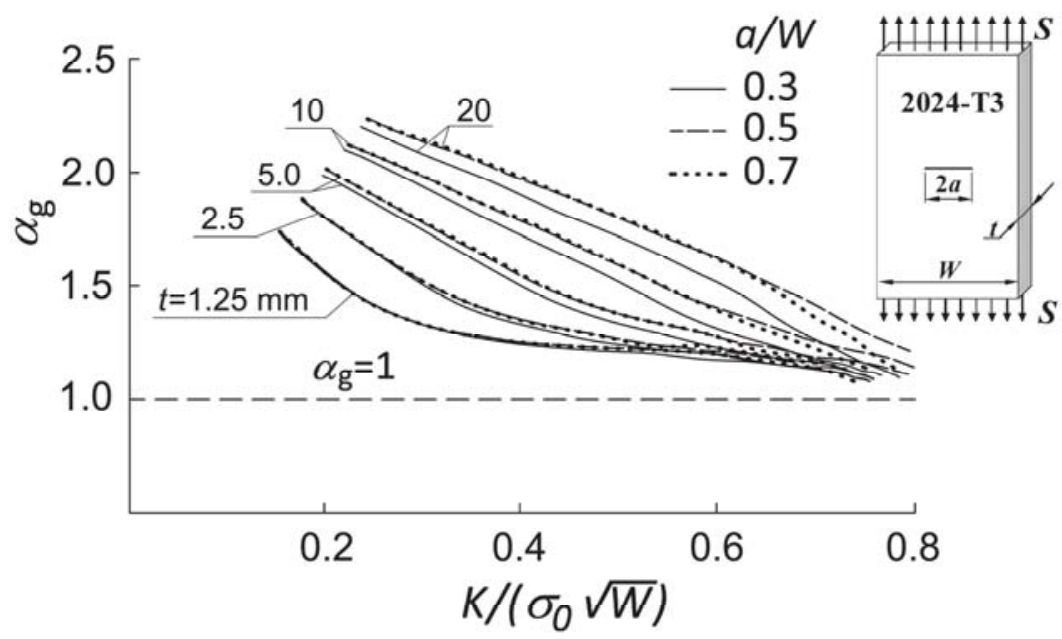

Fig. 3. The global constraint factor $\left(\alpha_{g}\right)$ variations determined by Newman at al. (1993) based on FEM analysis 
crack tension, aluminium alloy 2024-T351 specimens they developed the following equations for $\alpha_{t}$ :

$$
\begin{gathered}
\alpha_{t}= \begin{cases}-0754 \phi^{3}+ & \\
& \text { for } \phi \geq 1.15 \\
1.0 & \text { for } 0.27<\phi<1.15, \\
+5.179 \phi^{2}-8.219 \phi+4.864 & \text { for } \phi \leq 0.27 \\
3.0 & \end{cases}
\end{gathered}
$$

with $\phi=\Delta K /\left(\sigma_{0} \sqrt{t}\right)$.

Compared to a constant $\alpha_{t}$ - value, Eq. 5 yielded an improved correlation between the predictions and experiments, especially for CA loading conditions. In the case of OLs, more adequate predictions were achieved when $\alpha_{t}=1$ was assumed in the OL-generated plastic zone.

Currently, the most widely used SY model implementations are those included in the commercially available NASGRO software package (NASA, 2002). One of these is the so-called constant constraint-loss model further referred to as the CCL model which, minor differences apart, conforms to the FASTRAN II model by Newman (1992). The CCL model employs a constraint factor on tensile yielding only, which is of the same value for all elements in the crack tip plastic zone. The assumed dependency of $\alpha_{t}$ on stress conditions at the crack tip is based on experimental observations by Schijve (1981) indicating that a gradual transition of the fracture surface morphology from tensile mode crack growth to shear mode crack growth (the so-called shear lips) occurs for Al alloy specimens under CA loading, as illustrated in Figure 4. Schijve reported that the shear lip formation was completed at approximately the same crack growth rate, irrespective of the $R$-ratio value. Newman (1992) assumed that under CA loading the transition of the fracture surface geometry is a manifestation of changing stress conditions at the crack tip from plain strain to plane stress, and hence of changing a constraint. In view of that, the CCL model incorporates $\alpha_{t}$ varying linearly from its plane strain value $\left(\alpha_{1}\right)$ corresponding to fully tensile crack growth to the plane stress value $\left(\alpha_{2}\right)$ associated with fully shear crack growth, Figure 4 . The $\alpha_{1}$-value must be chosen by the user, whilst $\alpha_{2}$ of 1.2 is assumed for all metals. The range of the constraint factor transient behaviour spans 1.5 decade of crack growth rates and its central point $(d a / d N)_{T}$ is defined as a rate corresponding to the effective stress intensity factor of

$$
\left(\Delta K_{e f f}\right)_{T}=\mu \sigma_{0} \sqrt{t}
$$

with a value of 0.5 suggested for the $\mu$ coefficient (Newman 1992, NASA 2002).

\section{MODIFICATION OF THE YIELD STRESS AT TENSILE AND COMPRESSION}

The constraint models addressed above assume constraint factors on compressive yielding in the crack tip compressive zone $\left(\alpha_{c}\right)$ and in the crack wake $\left(\alpha_{w}\right)$ equal to unity, which implies $\sigma_{c}=\sigma_{0}$ and $\sigma_{w}=\sigma_{0}$. Based on FE analyses indicating $\alpha_{c}$-values ranging between -1 and -3 , Newman (1992) suggested introducing a constraint factor on compressive yielding. Also Wang (1993) proposed accounting for a constraint on compressive flow referring to the Bauschinger effect. The above postulates are realized in the so-called variable constraint-loss SY model in the NASGRO software,

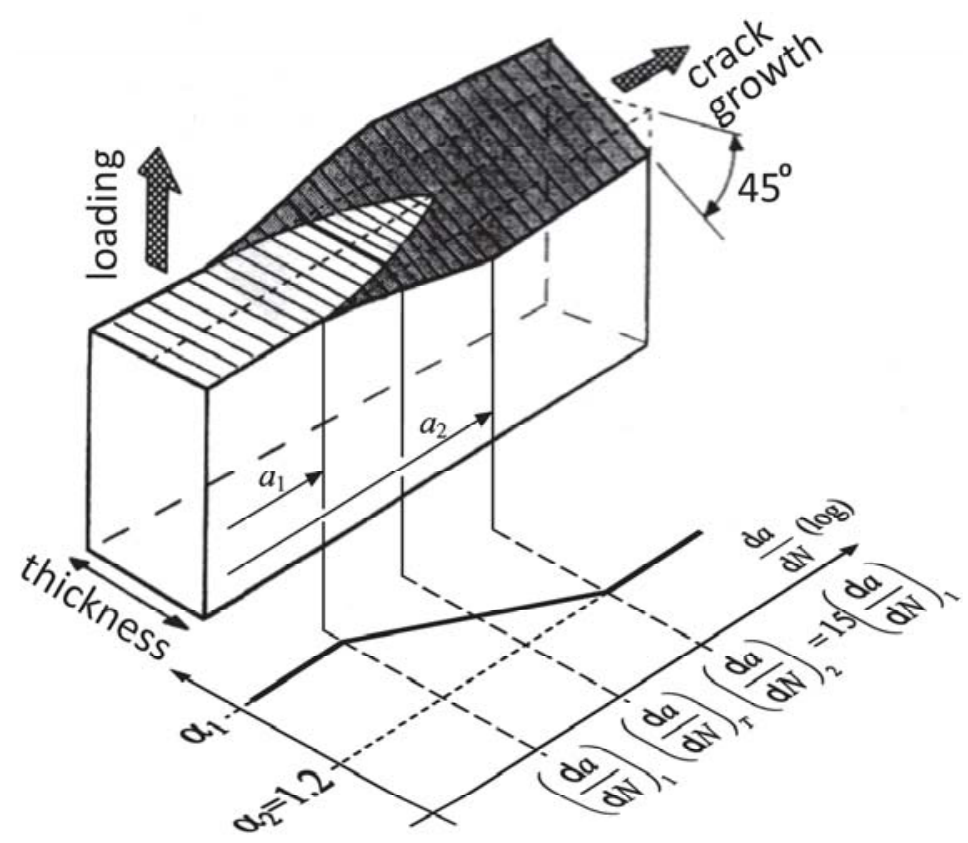

Fig. 4. The shear lips and corresponding to the constraint factor modification according to CCL-NASGRO model 
further termed the VCL model. This SY model implementation, initially referred to as the ESACRACK model, has been developed in the National Aerospace Laboratory in The Netherlands (Koning and Liefting 1987, Hoeve and Koning 1997, Grooteman and Hoeve 2006). With the VCL model, individual constraint factors are defined for each of the following four regions, as illustrated in Figure 5:

- tensile yielding of elements within the so-called primary plastic zone generated by a previous OL stress (peak stress 1),

- tensile yielding of elements within the so-called secondary plastic zone generated by the current $S_{\max }$ stress (peak stress 2),

- compressive yielding ahead of the crack tip,

- compressive yielding behind the crack tip (in the crack wake).

Contrary to the SY models addressed above, the constraint factor on tensile flow incorporated in the VCL model varies within the tensile plastic zone and is assumed to decay from an $\alpha_{t i p}$-value at the physical crack tip to a plane stress value of $\alpha_{1}=1.15$ at the plastic zone boundary. The evolution of $\alpha_{t}$ between these two extremes is govern by the following equation:

$$
\alpha_{t}(\rho)=\left(\alpha_{t i p}-1.15\right) \rho^{2}-2\left(\alpha_{t i p}-1.15\right) \rho+\alpha_{t i p}
$$

where the $\rho$ parameter defines the position of the centre of an element in the plastic zone with $\rho=0$ for an element at the current crack tip and $\rho=1$ at the fictitious crack tip, i.e. at the boundary of the primary plastic zone. The $\alpha_{t i p}-$ value is chosen depending on the $r_{p} / t$ ratio, where $r_{p}$ is the plastic zone size at the current $S_{\max }$ computed assuming plane stress conditions $(\alpha=1.15)$. Due to the dependency of $\alpha_{t}$ on the strip element position ( $\rho$, cf. eq. 7 ), iteration procedure is needed to compute $r_{p}$.

The $\alpha_{c}$ constraint factor included in the VCL model is assumed to be identical for all elements in the compressive plastic zone ahead of the crack tip and is given by

$$
\alpha_{c}=\frac{\alpha_{\text {tip }}}{\alpha_{\text {new }}}
$$

where $\alpha_{n e w}$ is a material parameter associated with differences in the material response to compressive and tensile loading.

Broken elements behind the crack tip are assigned another constraint factor $\left(\alpha_{w}\right)$ defined as

$$
\alpha_{w}=\frac{1}{\alpha_{\text {new }}}
$$

or

$$
\alpha_{w}=\frac{1}{\alpha_{n e w}} \cdot f_{1}\left(S_{\max } / \sigma_{y}\right)
$$

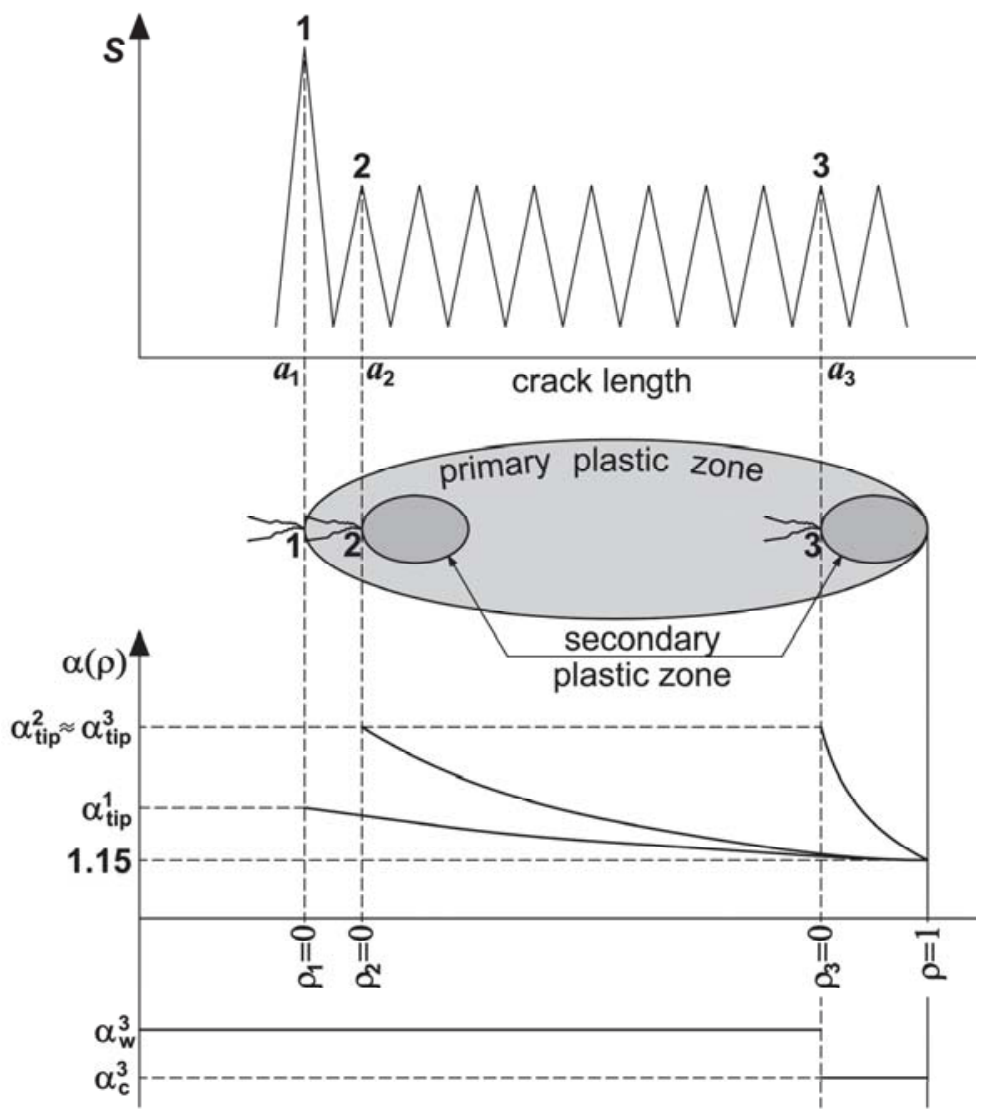

Fig. 5. Constraint factors in overload plastic zone according to VCL-NASGRO model (Grooteman and Hoeve 2006) 
where the $f_{1}\left(S_{\max } / \sigma_{y}\right) \in\left\langle 1-1.2 \alpha_{t}\right\rangle$ function is determined by table looking.

Eq. 9a is according to an earlier concept by Hoeve and Koning (1997) modified more recently to the form of Eq. 9b by Grooteman and Hoeve (2006).

It is worth noting that the non-linear distribution of $\alpha_{t}=f(\rho)$ in the plastic zone (cf. Eq. 7) can be interpreted as an approach to model strain hardening of the material. Literature evidence provides an alternative means of accounting for the strain hardening effect, both in the SY model (Daniewicz 1994, Wang at al. 1998) and in the Dugdale model (Hoffmann and Seeger 1985, Neimitz 2004).

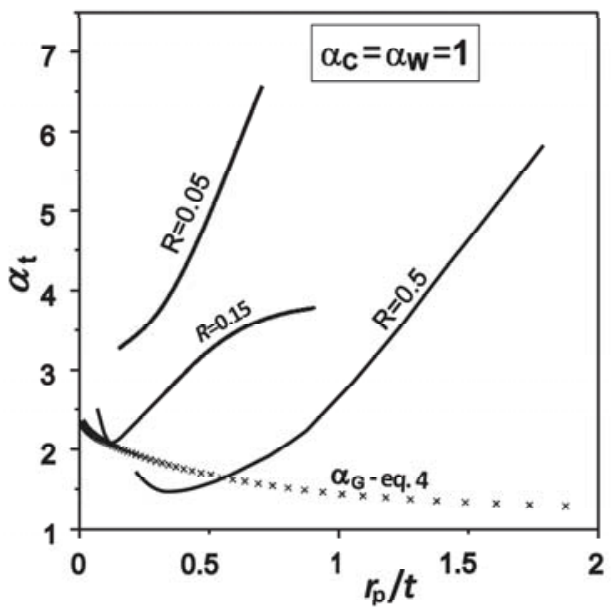

Fig. 6. Variations of the constraint factor on tensile yielding $\left(\alpha_{t}\right)$ for the constant amplitude loading required to cover the stress ratio effect observed in fatigue crack growth tests of structural steel 18G2A
Also the present author and co-workers demonstrated (Skorupa et al. 2002) the $\alpha_{G}$ factor is not capable of correlating the observed fatigue crack growth behaviour in structural steel (18G2A acc. PN-EN 10028 ). As it is presented in Figure 6 to match the predicted and observed crack growth rate at the constant amplitude tests the required $\alpha_{t}$ reached extremely high value. This consequently yield very small plastic zone sizes and unduly low crack growth increments which precludes the crack growth simulation. Simultaneously the requited trend of $\alpha_{t}$ variations increases with increasing $r_{p} / t$, contrary to $\alpha_{G}$ described by eq. (4). These results revealed that in order to cover the observed stress ratio effect on crack growth by the SY model predictions, three independent constraint factors are required: $\alpha_{t}, \alpha_{c}$ and $\alpha_{w}$. Because, however, the required value of the crack opening stress $\left(S_{\mathrm{op}}\right)$ can be obtained for many combinations of the three independent a-values, an additional criterion for their selection had to be adopted, namely matching the experimentally observed and predicted by the model local cyclic stress-strain behaviour. The observed cyclic stress-strain response of the material is represented by the stress vs. offset strain $\left(S\right.$ - $\left.\varepsilon_{\text {offset }}\right)$ diagrams derived from compliance measurements (Skorupa et al. 2009). The predicted $S$ - $\varepsilon_{\text {offset }}$ loop at the gage location was obtained by using Beretta and Carboni (2005) approach which allows analytically determine the cyclic strain variations measured by a strain gauge, based on the SY model solution on the strip element stresses for assumed constraint factors values. An exemplary comparison between the observed and computed $S$ - $\varepsilon_{\text {offset }}$ data for various combinations of the three constraint factors is shown on Figure 7. It is assumed that both type loops are similar if the loop widths (a measure of the cyclic plasticity) and the total offset strain ranges (reflecting the overall shape of the $S$ - $\varepsilon_{\text {offset }}$

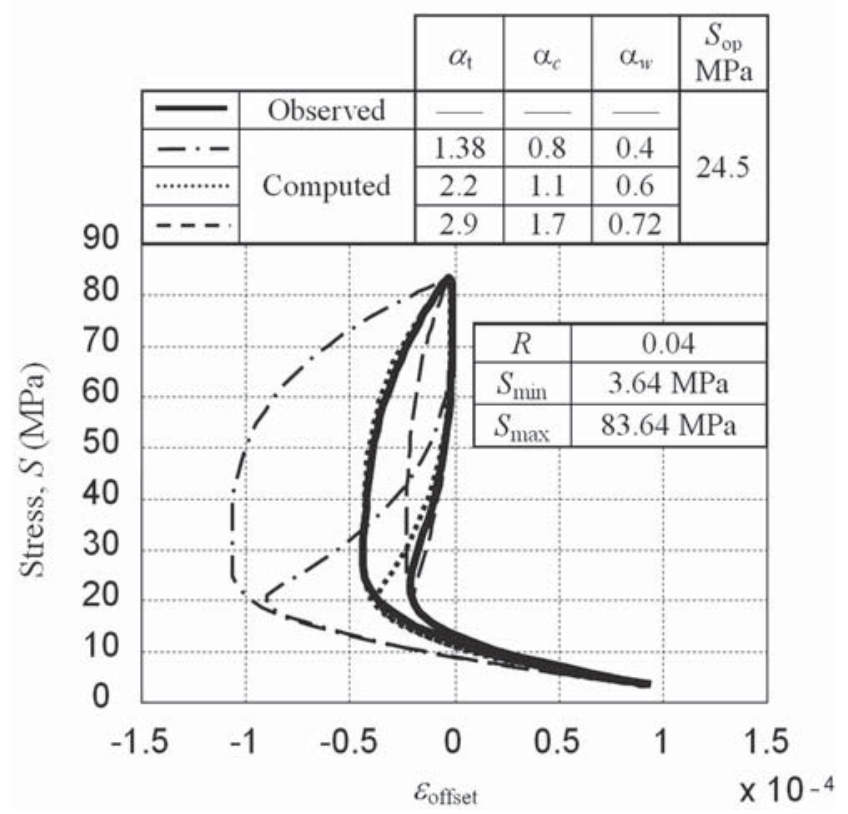

Fig. 7. Exemplary comparisons between the observed and simulated $S-\varepsilon_{\text {offset }}$ loops for various combinations of the three constraint factors 
data) are approximately the same. Matching the predicted and observed loops automatically yields a matching between the predicted and observed $S_{o p}$ levels.

\section{DISCUSSION AND CONCLUSIONS}

The literature evidence including the works referred to in section 2 and the present author's experience (Skorupa et al. 2002, Skorupa et al. 2005, Skorupa et al. 2007a, Machniewicz 2012) indicates that another important role of the constraint factors, in addition to accommodating in the SY model the triaxial stress state, is covering indirectly various processes which do affect crack growth, but cannot be treated in a rigorous way. These include the material strain-stress response under monotonic and cyclic loading, microstructure, alternative to plasticity induced crack closure mechanisms, etc. The description of the constraint behaviour makes a model in itself and is critical to the model predictive capabilities. The constraint conception is crucial for the SY model prediction quality. For example, Skorupa et al. (2007b) concluded that altogether unsatisfactory prediction quality of SY models implemented in the NASGRO software shown in applications to aluminium alloys under a variety of CA and VA loading conditions stemmed from an inadequate conception of the constraint factors. Specifically, neither model was capable of correct reproducing crack growth retardation observed after a single overload cycle. Consequently, overly conservative predictions followed for VA load histories causing large retardation effects. For CA loading the NASGRO VCL model produced considerably better results than the CCL model.

An inadequacy of constraint factor conceptions developed for SY model applications to Al alloys is clearly demonstrated by results of Skorupa et al. (2002) and Skorupa et al. (2005). Skorupa et al. (2002) reported that the $\alpha_{G}$ constraint factor (cf. eq. 3) was not capable of correlating by their SY model the Sop behaviour measured in structural steel under CA loading for a variety of R-ratios because, contrary to the required trend, $\alpha_{G}$ decreases with increasing $r_{p} / t$. This study also indicated that to achieve agreement between the predicted and experimental $S_{o p}$ stresses through elevating the tensile flow stress only, unrealistically high $\alpha_{t}$ levels are needed. However, even with the considerably more complex constraint modelling incorporated in the NASGRO VCL and CCL codes it was not possible to predict the effect of the R-ratio on crack growth for structural steel (Skorupa et al. 2005). Even when very high values of $a_{1}$ and $\alpha_{\text {new }}$ were assumed (see section 2 ), either model predictions exaggerated the observed $R$-ratio effect.

With a novel conception of tuning the SY model for structural steel proposed by the present author and co-workers (Skorupa et al. 2009, Machniewicz 2012), three independent constraint factors $\left(\alpha_{t}, \alpha_{c}\right.$ and $\left.\alpha_{w}\right)$ are selected by matching the experimentally observed and predicted by the SY model local cyclic stress-strain behaviour. The SY model incor- porating the above, based on a sound physical foundation, constraint factors produced was proved to yield excellent crack growth predictions under a variety of CA loading conditions. To simulate, however, the post-OL transient crack growth behaviour, an additional empirically coefficient had to be introduced to the constraint model. Though the SY model could then provide good predictions also for single and block OLs periodically applied, it was still not capable of correlating enhanced crack growth retardation due to a single block of OL cycles. Evidently, new parameters would be needed to improve the SY model performance for this type of loading on structural steel.

Altogether, investigations reviewed in this paper justify the conclusion that in order to cover the spectrum of events which may occur in VA load histories a variety of material and load sequence related parameters would be needed in the SY model. The model calibration for a new material would, therefore, require an excessive number of carefully planned experiments. An alternative, more pragmatic approach is to tailor the SY model to a particular load spectrum type. Reliable predictions could then be obtained for practical purposes, as for example comparing the spectrum severity or studying the influence of certain load variables and material properties in order to evaluate the damage tolerance of the structure.

\section{References}

Beretta S, Carboni M. 2005, A strip yield algorithm for the analysis of closure evaluation near the crack tip, Engineering Fracture Mechanics, vol. 72, pp. 1222-1237.

Danielecki S. 1997, Reliability accounting models on fatigue cracks development, Zagadnienia Eksploatacji Maszyn, vol. 32, No 2(110), pp. 191-204 (in Polish).

Daniewicz S.R. 1994, A closed form small-scale yielding collinear strip yield model for strain hardening materials, Engng. Fracture Mech. vol. 49, No. 1, pp. 95-103.

Elber W. 1970, Fatigue crack closure under cyclic tension, Engng. Fracture Mech., vol. 2, No. 1, pp. 37-45.

Grooteman F.P., Hoeve ten H.J. 2006, ESACRACK Strip Yield variable constraint model, Report No. NLR-CR-2006-390, NLR, The Netherlands.

Guo W., Wang C.H., Rose L.R.F. 1999, The influence of cross-sectional thickness on fatigue crack growth, Fatigue Fract. Engng. Mater. Struct., vol. 22, No. 5, pp. 437-444.

Hoeve ten H.J., Koning de A.U. 1997, Reference Manual of the Strip Yield Module in the NASGRO or ESACRACK Software for the Prediction of Retarded Crack Growth and Residual Strength in Metal Materials, Report No. NLR TR 97012, NLR, The Netherlands.

Hoffmann M., Seeger T. 1985, Dugdale solutions for strain hardening materials, [in:] K.H. Schwalbe (Ed.) The Crack Tip Opening Displacement in Elastic-Plastic Fracture Mechanics, Workshop on the CTOD Methodology, Geesthacht, Germany, April 1985, pp. 57-77.

Koning de A.U., Liefting G. 1987, Analysis of crack opening behavior by application of a discretized strip yield model, Report No. NLR MP 87065 U, NLR, The Netherlands.

Machniewicz T. 2012, Fatigue crack growth prediction in selected metallic materials, AGH University Press - in print (in Polish).

McMaster F.J., Smith D.J. 2001, Predictions of fatigue crack growth in aluminium alloy 2024-T351 using constraint factors, Int. J. Fatigue, vol. 23, Suppl., pp. S93-S101.

NASA 2002, Fracture mechanics and fatigue crack growth analysis software. Reference manual Version 4.02, NASA Lyndon B. Johnson Space Center, Texas 2002. 
Neimitz A. 2004, Modification of Dugdale model to include the work hardening and in- and out-of-plane constraints, Engng Fracture Mech., vol. 71, No. 11, pp. 1585-1600.

Newman J.C. 1981, A crack closure model for predicting fatigue crack growth under aircraft spectrum loading, [in:] J.B. Chang C.M Hudson (Ed.) Methods and Models for Predicting Fatigue Crack Growth under Random Loading, ASTM STP 748, Philadelphia, pp. 53-84.

Newman J.C. 1982, Prediction of fatigue crack growth under variable-amplitude and spectrum loading using a closure model, [in:] P.R. Abelkis, C.M. Hudson (Ed.) Design of Fatigue and Fracture Resistant Structures, ASTM STP 761, Philadelphia, pp. 255-277.

Newman J.C. 1992, FASTRAN II - A fatigue crack growth structural analysis program, NASA Technical Memorandum No. 104159. NASA Langley Research Center, Hampton, USA.

Newman J.C., Bigelow C.A., Shivakumar K.N. 1993, Three-dimensional elastic-plastic finite-element analysis of constraint variations in cracked bodies, Engng. Fracture Mech., vol. 46, No. 1, pp. 1-13.

Schijve J. 1981 Shear lips on fatigue fractures in aluminium sheet material, Engng Fracture Mech., vol. 14, No. 4, pp. 789-800.

Skorupa M. 1996, Empirical trends and prediction models for fatigue crack growth under variable amplitude loading, ECN-R--96 007, Netherlands Energy Research Foundation (ECN), Petten, The Netherlands

Skorupa M. 1998, Load interaction effects during fatigue crack growth under variable amplitude loading - a literature review. Part I: Empirical trends, Fatigue Fract. Engng. Mater. Struct. vol. 21, No. 8 , pp. 987-1006.

Skorupa M., Machniewicz T., Skorupa A., Carboni M., Beretta S. 2002, Experimental and theoretical investigation of fatigue crack closure in structural steel, Proc. of 8th Int. Fatigue Conf. (Fatigue 2002), Stockholm, Sweden, June 2002, vol. 4/5, pp. 2309-2316.

Skorupa M., Machniewicz T., Skorupa A., Beretta S., Carboni M. 2005, Application of the strip-yield crack closure model to crack growth predictions for structural steel, Proc. of 11th Int. Conf. of Fracture (ICF11), Turin, Italy, March 2005, Paper No. 3525.

Skorupa M., Skorupa A., Machniewicz T. and Korbel A. 2007a, Calibration of the Strip Yield model for the predictions of crack growth in structural steel. Final report on the KBN project 4 T07C 018 26. AGH University of Science \& Technology, Kraków, Poland (in Polish).

Skorupa M., Machniewicz T., Schijve J., Skorupa A. 2007b, Application of the strip yield model from the NASGRO software to predict fatigue crack growth in aluminium alloys under constant and variable amplitude loading, Engng. Fracture Mech., vol. 74, No. 3, pp. 291-313.

Skorupa M., Machniewicz T., Skorupa A. 2009, Crack growth predictions for structural steel using the strip yield model, Proc. of 2nd International Conference on Material and Component Performance under Variable Amplitude Loading (VAL2), March 23-26, 2009, Darmstadt, Germany, vol. II, pp. 413-422.

Sobczyk K., Spencer B.F. 1992, Random Fatigue: From Data to Theory, Academic Press, Boston.

Wang G.S., Blom A.F. 1991, A strip model for fatigue crack growth predictions under general load conditions, Engng Fracture Mech., vol. 40, no. 3, pp. 507-533.

Wang G.S. 1993, The plasticity aspect of fatigue crack growth, Engng. Fracture Mech., vol. 46, No. 6, pp. 909-930.

Wang J., Gao J.X., Guo W.L., Shen Y.P. 1998, Effects of specimen thickness, hardening and crack closure for the plastic strip model, Theoret. Appl. Fracture Mech., vol. 29, No. 1, p. 49-57. 